\title{
Social Acceptance for Floating Houses as Alternative Residential in Coastal Area
}

\author{
Henny Pratiwi Adi ${ }^{*}$, Jorge Jansen ${ }^{2}$, and Rick Heikoop ${ }^{2}$ \\ ${ }^{1}$ Civil Engineering Department of Sultan Agung Islamic University , Jl. Raya Kaligawe Km.4 \\ Semarang,Indonesia \\ ${ }^{2}$ Water Management Department of Rotterdam University of Applied Science, G.J de Jonghweg 4-6, \\ Rotterdam The Netherlands \\ *Corresponding author: henni@unissula.ac.id
}

(Received: July $14^{\text {th }}, 2020$; Revised: October $4^{\text {th }} 2020$; Accepted: October $14^{\text {th }} 2020$ )

\begin{abstract}
Semarang as a city located in the coastal area is dealing with the some problems, such as rising sea level, land subsidence, scarcity of land and illegal settlers. In order to deal with rising sea level, a polder system is developed in Kemijen (northern of Semarang). This polder system depends on dredging, a pumping station and retention basins to store water. To make the polder function well and reduce the floods, the existing retention basins should be expanded. Therefore, people who are living at the borders of these basins should be relocated or floating houses could be a solution.. This study aims to determine the acceptance of the Kemijen inhabitants towards floating houses as alternative residential in coastal areas. Data collecting in this study were obtained through interviews with the Kemijen residents and stakeholders. The data then processed by SWOT analysis. Based on the research result, it can be concluded that the social acceptance of the inhabitants is quite low, but there is potential because they see positive elements in a floating house. According to the survey most inhabitants do have insufficient income to pay for a floating house. Building on water is still not legal in Indonesia and therefore the law should probably be adjusted. Besides the land owner is still reluctant in building legal houses on its land. In order to improve the social acceptance of floating houses, these factors should be strengthening, namely relative advantages, compatibility, complexity, trialability and observability.
\end{abstract}

Keywords: floating house; flood; social acceptance

\section{Introduction}

Coastal area, is an area that must face various problems due to climate change. Increased coastline that shifted to the mainland resulting in tidal waves will rise to the mainland, damage the facilities and infrastructure of the coastal area and inundate the buildings above it. The impact will disrupt the activities of the population and make the settlement and infrastructure damaged. This makes a heavy loss for the government and people affected by rising sea levels [4].

Kemijen is an area in the north of Semarang. This area is often flooded due to rising sea levels, which results in flooding of settlements by residents. Impacts that occur are damage to roads and the environment, low sanitation and increased risk of disease [9]. In order to deal with rising sea level, a polder system is developed in Kemijen. This polder system depends on dredging, a pumping station and retention basins to store water [6]. To make the polder function well and reduce the floods, the existing retention basins should be expanded. Therefore, people who are living at the borders of these basins should be relocated or floating houses could be a solution. 
A floating houses is a building structure that floats on water by relying on the weight of the area submerged as a load parameter that can be borne by the structure [1] [4]. Floating houses is one solution to prevent overcrowding in urban settlements. With land and house prices in urban areas becoming more expensive, floating houses are an alternative for urban planners and builders [5].

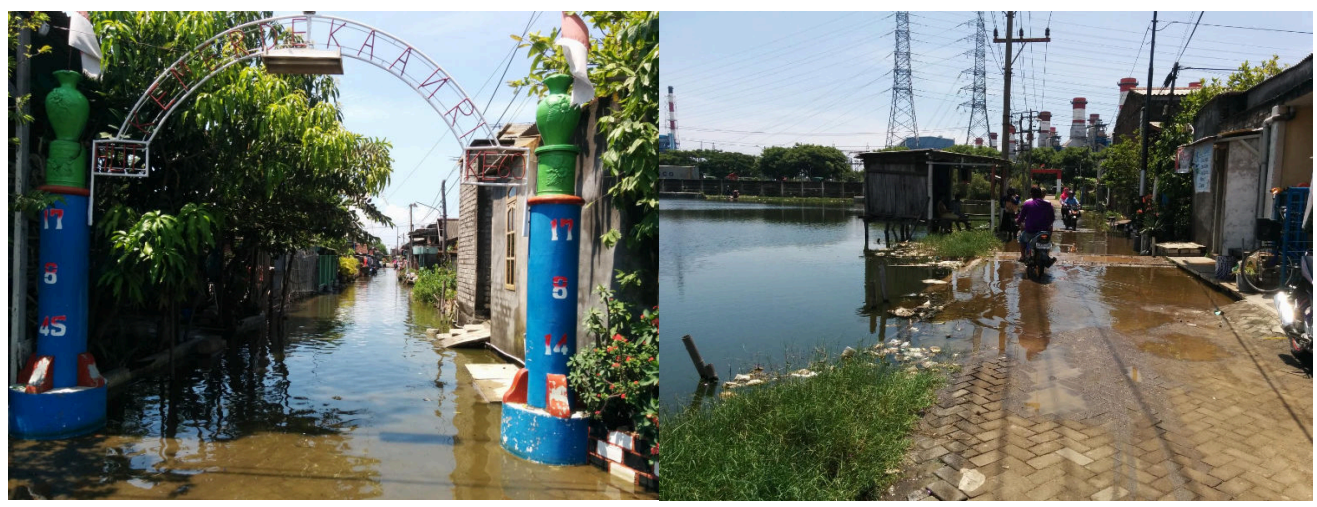

Fig. 1. Flooding Condition in Kemijen

Before implementing it is important to do research into the social feasibility of floating houses. The social feasibility depends on the social acceptance of floating houses and the social preconditions. This study aims to determine the acceptance of the Kemijen inhabitants an stakeholders towards floating houses as alternative dwellings in coastal areas that are experiencing the impact of rising sea levels. Living in a floating houses on water will certainly change the habits and lifestyle of the inhabitants. Therefore, understanding and readiness of the inhabitants is needed so far that are accustomed to living in houses that are above the ground.

\section{Literature Review}

\subsection{Floating Houses}

Dealing with water related issues has always been a challenge in many parts of the world. Especially in high density areas along rivers near the coast: the Delta Cities. With the rising of the sea level, climate change and land subsidence delta cities have to adapt to the changing conditions in order to keep the city safe from flooding. Only heighten the embankments is in most situations not enough. A combination of different solutions must be applied [1] [4]. Climate change causes more heavy rainfall in a shorter period of time. Therefore, city planners should organize the city in a way that it can adapt to the extra water. This requires extra storage zones and demands more space and more flexible management. Besides water related issues there is another problem where city planners have to deal with: the lack of space. In many cities there is an urgent need for urban development [10]. The number of city dwellers is expanding and this requires an increase of space for housing area. The demand for extra water storage and space for housing are in conflict with each other. This conflict will grow in the future when the demands are growing through climate change and growth of the population. City planners should therefore search for other possibilities [7].

Multiple use of space seems the solution for this problem. Floating houses are an excellent example of multiple land use [8]. Combining different functions in a city can help to reduce the water problems and provides more space for living areas. Figure 2 gives an impression of floating house that can be implemented in vulnerable delta areas. 


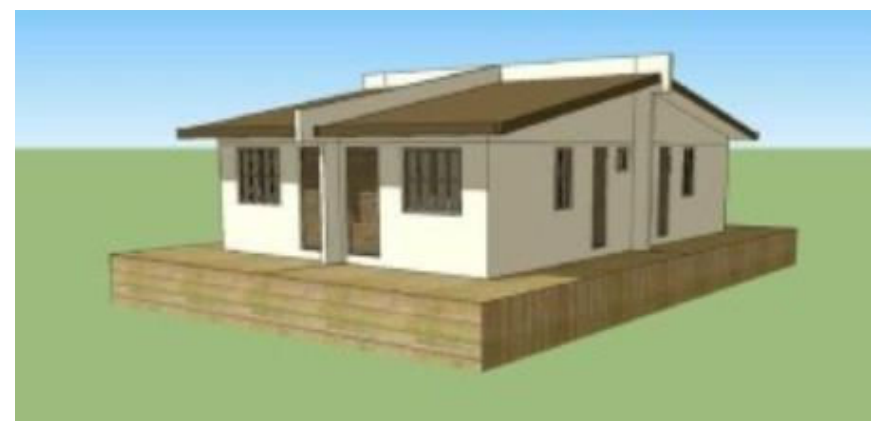

Fig. 2. Impression of a Floating House

Jansen (2017) has done research about the feasibility of floating houses in the Netherlands. The core of his research is getting insight into the relationship between the history of living near and on water. In his research Rijcken describes four main points. 1) The historical classic values of water such as transportation, recreation, pleasing reflection etc. attracts human; 2) There are several benefits of living on the water comparing to living near the water : bohemia, manipulating legislation and the benefits of mobility; 3) A floating houses can be technically advanced to give it more value. But it is more expensive to provide a floating house with these values than for a normal house; 4) Floating houses in the future can be developed because of the historical motives, but these motives will not be strong enough for a "floating breakthrough".

\subsection{Social Acceptance}

The definition of social acceptance by examining various definitions that have been proposed in other literature sources. In their paper they also illustrate the main factors that influence social acceptance such as culture, time, interaction type and user's position on the innovation adoption curve [6].

In order to bring a new product on the market it is important to understand what the requirements are of your target market. According to Jansen (2017) many innovations requires a long period between the availability and the widely adaptation. Therefore it is for companies important to know how to speed up the rate of diffusion of an innovation. In his paper Diffusion of innovations Jansen (2017) describes how the diffusion of innovation works and how it can be accomplished. (Santosa et al., 2017) also describes the diffusion of a new innovation. According to them there are five characteristics of innovation that affect the diffusion [8]:

1. Relative advantage (the amount of improvement relative to currently available technology)

2. Compatibility (the degree of consistency of social practices and norms of users)

3. Complexity (it should be easy to use or learn)

4. Trialability (the opportunity to try an innovation before using it)

5. Observability (the extent wherein the technology's advantages are present)

Different studies have demonstrated that innovations with good advantages, compatibility with existing beliefs and practices, low complexity, possibility for a trial and observability will be diffused more easily than innovations with the opposite characteristics.

\section{Methodology}

Determine the social acceptance of communities, requires interviews with the inhabitants of Kemijen. The social acceptance of the inhabitants is determined with 35 respondens that have been done in the area of Kemijen. This is only a small amount of the total population of Kemijen (13.000). But because this research is making use of a sample these surveys can represent the population. Besides during the selection of the participants the variety of the inhabitants is taken into account. The surveys were hold in many different streets and areas in Kemijen. 
In order to understand the circumstances, the context and to verify some elements, it is also important to interview different stakeholders. Table 1 below, describes who will be interviewed, the reason of interviewing and the method of the interviews.

Table 1. Selected Interviewee

\begin{tabular}{|c|c|c|c|}
\hline Interview & Method & Selected because & Position \\
\hline Inhabitants & Interview & $\begin{array}{l}\text { The inhabitants are the most important } \\
\text { stakeholders for this research. They will be } \\
\text { the future users for floating houses so it is } \\
\text { important to know what their opinion is about } \\
\text { floating houses. }\end{array}$ & User \\
\hline PT. KAI & $\begin{array}{l}\text { Open } \\
\text { discussion }\end{array}$ & $\begin{array}{l}\text { PT. KAI is the owner of the land of the } \\
\text { retention basins. They rent the land to the } \\
\text { municipality for a certain period, but making } \\
\text { floating buildings requires a contract for a } \\
\text { longer period with this organization }\end{array}$ & Stakeholder \\
\hline PSDA & $\begin{array}{l}\text { Open } \\
\text { discussion }\end{array}$ & $\begin{array}{l}\text { PSDA a governmental department and is } \\
\text { responsible for the water management of } \\
\text { Semarang. Even though the daily } \\
\text { management of the polder will be done by } \\
\text { SIMA, PSDA is still responsible for the long } \\
\text { term investments and maintenance. }\end{array}$ & Stakeholder \\
\hline BAPPEDA & $\begin{array}{l}\text { Open } \\
\text { discussion }\end{array}$ & $\begin{array}{l}\text { BAPPEDA is part of the municipality of } \\
\text { Semarang and highly involved in the Banger } \\
\text { Polder project. }\end{array}$ & \\
\hline $\begin{array}{l}\text { Lurah of } \\
\text { Kemijen }\end{array}$ & $\begin{array}{l}\text { Open } \\
\text { discussion }\end{array}$ & $\begin{array}{l}\text { The Lurah is the social leader of Kemijen. He } \\
\text { is involved in the social events in the area } \\
\text { and a contact person for inhabitants. }\end{array}$ & Stakeholder \\
\hline
\end{tabular}

Methods derived from several literature resources will be used in order to make a clear overview. Answers of open questions will be summarized and clarified. There are four aspects discussed in the interview and open discussion, namely maintenance and management aspect, juridical aspects, financial aspects and technological aspects.

With the gathered information a SWOT (Strengths, Weaknesses, Opportunities, Threats) analysis will be set up. The SWOT analysis identifies the internal strength and weak factors of the project [3]. The outcomes also provide insight into the external factors opportunities and threats. These are factors where the organization has less control on but that are important to take into consideration.

\section{Results and Discussions}

\subsection{Banger Polder Project}

In February 2003 a cooperation is set upbetween the Indonesian government and the government of the Netherlands to develop a polder, The Banger Polder. The project consists of flood management facilities development and institutionaldevelopment. The Banger Polder should be an example of polder system implementation for the restof Semarang City, other cities in Indonesia and even for other countries in Southeast Asia.

This polder system should prevent the area from flooding. The water level in the polder area can beartificially controlled to a preferred water level, which deviates from the surrounding regional open water levels. The dikes surrounding the area separate the system from the regional hydrologicalsystem. The polder will consist of drains, retention basins, control structures (weir, 
gates, etc.) and outlet structures (pumping stations). When the regional water level is permanently above thedesired inner water level, the pumping station is the critical factor. The success of the polderdepends on the working of this pumping station and should therefore need a proper maintenance.

The polder in Semarang is needed because of the flooding problems that occur on a daily basis at themoment. These problems are becoming bigger since the land subsidence in Semarang is still happening. In the most vulnerable areas this land subsidence is between $5 \mathrm{~cm}$ up to $15 \mathrm{~cm}$ per year. The current dimension of the retention basins is 9 ha. This is too small for the required safety level. For the measured safety level the basins should contain water up to a T10 rainfall event. This safetynorm requires an extension of the basins up to $12 \mathrm{ha}$. With an extension of the basins, householdaround the basins will be affected. The government want to replace these people, but with floatinghouses it will be possible for inhabitants to keep living in their neighborhood safely. Figure 3 schematizes what will happen if the basins are expanded with and without floating houses.

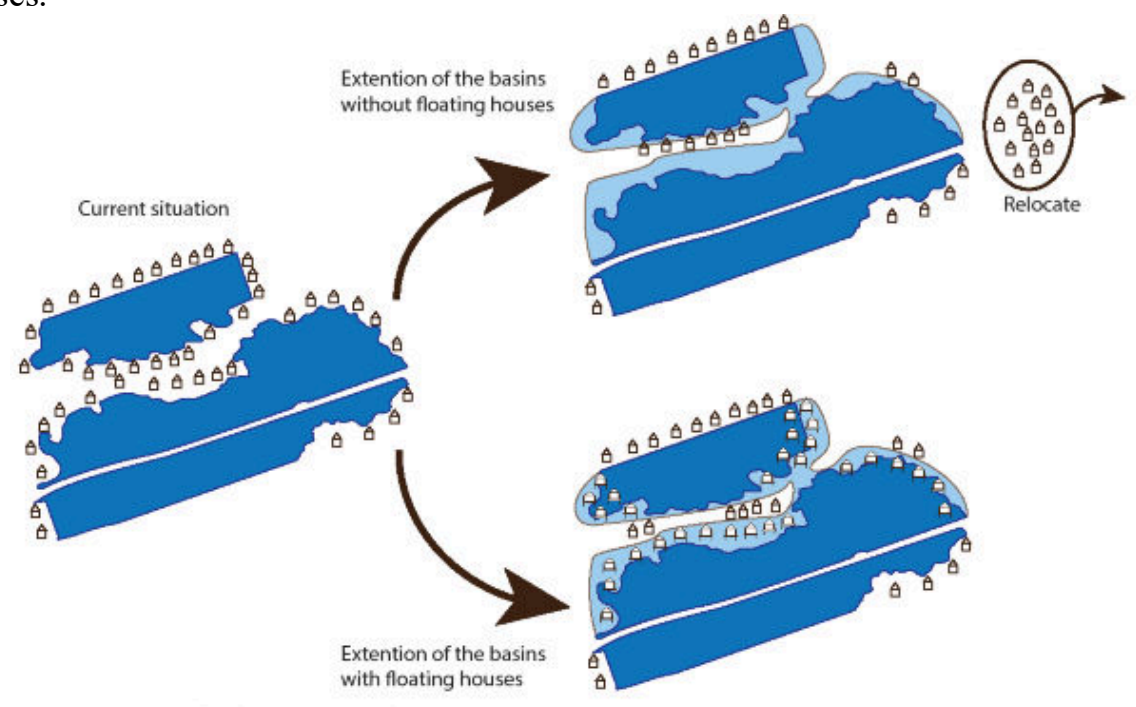

Fig. 3. Schematic Effect of The Extention of The Basins

\subsection{Kemijen Area}

In the north of the Banger Polder the district Kemijen is located. This district is the lowest part of the Banger Polder and is facing many floods. Kemijen is one of the most vulnerable areas in Semarang and also one of the poorest areas. The variety of 13.000 inhabitants that lives in Kemijen is diverging. Most people work at the informal urban sector [2]. The inhabitants who work at the harbor or factories around the area do have more money to spend. The poorest people are the retired population.

The retention basins in Kemijen do have a multiple function. At first the basins are required as water storage for the functioning of the Banger Polder. Besides these basins are also an important source of income of the fishermen. Because the water in the basins is brackish, it provides a good habitat for many fish species. The fisherman sell their fish at the formal and informal sector is Semarang.

PT Kereta Api Indonesia (KAI) is the owner of the land where the retention basins are located. This used to be an area for train depot. For PT KAI it is important that the water problems are being solved since they face high economic losses due the floods. Besides they are an important stakeholder because they rent their land to the municipality for the implementation of the retention basin. 


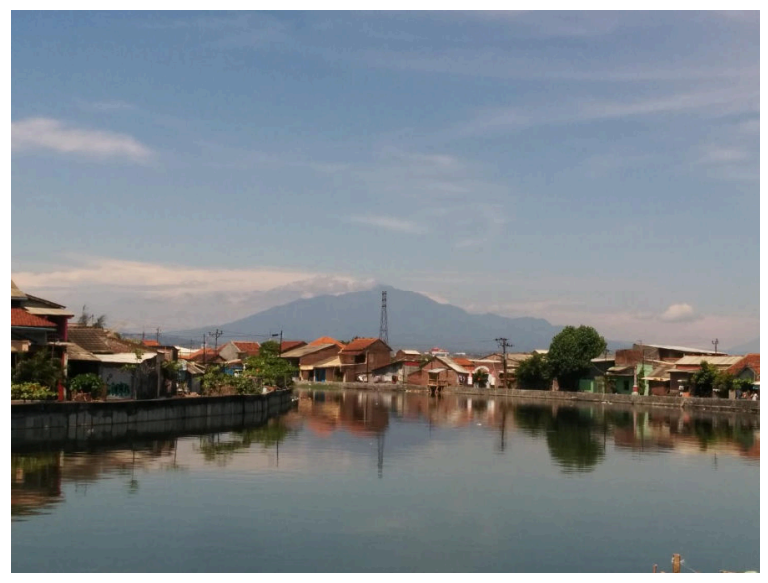

Fig. 4. Retention Basins in Kemijen

\subsection{Results of Interview}

During the interviews some inhabitants give some responses. These responses are are important to understand the current conditions in Kemijen.

To discuss the outcomes and gather the opinion of society, a focus group session is held. A regulation of the government is required for floating houses because in Semarang it is still illegal to build above the water. Dirty culture is a problem in Kemijen. Inhabitants throw their waste anywhere and do not take care of the environment. Solid and human waste ends up untreated in the environment. This makes the area, especially the water, an unhealthy to live. A change of mindset is necessary in order to get a clean environment and making living on the water suitable. The price of IDR 100.000 per week is too expensive for families in Kemijen. Besides is the estimated area of a floating house $\left(25 \mathrm{~m}^{2}\right)$ too small for a family. For a boarding house this could be possible. The water in the polder is brackish at this moment. When the implementation is completed the water will become fresh. Before implementing it is important to measure the current conditions of the water. If the water is still containing salt, the material of the floating structure should be made suitable for the salty water.

For implementing floating houses, not only the social acceptance is important. There are several other aspects which have to be taken into consideration. In the aspect of maintenance and management, before implementing a floating house in Semarang, it is very important to make a plan for the maintenance. What maintenance should be done and who will be responsible for it. This element is important to take into account but lays beyond the research boundaries. The research into the social aspects does have to take place in an earlier stage.

In the aspect of juridical, floating houses on the retention basin of Semarang do have juridical restrictions. What these restrictions are should be clarified before the implementation. For the juridical elements the ownership and law are important. But before research into this element can take place, the social feasibility and urgency should be determined first.

In the financial aspects, if people see the utility and accept the concept of floating houses, it doesn't mean they are able to pay for the houses. Financial support of other parties is probably necessary to provide floating houses for the poor inhabitants. For this research inhabitants will be asked if they are willing to pay extra for a floating house and if it is possible for them to pay extra. This is important for the social acceptance because people wouldn't accept a house which is too expensive for them. People who are living near the retention basin are poor. The government has built legal apartments for them, but the rent of IDR 500.000 is too much for most of the poor residents. The implementation of floating houses in Semarang will cost around IDR 100.000 per week. This includes a self-sufficient system. The inhabitants were asked what they are paying for their current house, and if they would pay IDR 100.000 for a floating house. According to the 
surveys in Kemijen IDR 100.000 per week is too much for most inhabitants. They currently pay about IDR 2 -3 million per year for a house. Besides there current house is bigger and stronger that a floating house.

In technological aspects, technological preconditions for the design of the house are set up by FlexBase and Metabolic. The house will be made of local available materials, such as wood and bamboo. The floating forces will be made by Styrofoam and concrete. According to the inhabitants and BAPPEDA, people don't want to live in houses made of wood and bamboo. Besides wood of a good quality is more expensive than concrete. This should be taken into account and therefore the concept should maybe be adjusted to make it more acceptable for inhabitants. The water in the polder is brackish at this moment. When the implementation is completed the water will become fresh. Before implementing it is important to measure the current conditions of the water. If the water is still containing salt, the material of the floating structure should be made suitable for the salty water.

\subsection{SWOT Analysis of Floating Houses}

With the gathered data during the field research and interviews in Semarang a SWOT (Strengths, Weaknesses, Opprtunities, Threats) analysis is setup. Result of SWOT analysis can be shown at Table below.

Table 2. SWOT Analysis

\begin{tabular}{llll}
\hline \multicolumn{1}{c}{ Strengths } & \multicolumn{1}{c}{ Weaknesses } & \multicolumn{1}{c}{ Opportunities } & \multicolumn{1}{c}{ Threaths } \\
\hline Multiple land use & Too expensive & $\begin{array}{l}\text { Pilot project in the } \\
\text { Banger Polder }\end{array}$ & $\begin{array}{l}\text { Lack of maintenance } \\
\text { will affect the } \\
\text { building }\end{array}$ \\
\hline $\begin{array}{l}\text { Reduce flooding } \\
\text { problems }\end{array}$ & $\begin{array}{l}\text { Most inhabitants } \\
\text { don't want to live in } \\
\text { houses made of wood }\end{array}$ & $\begin{array}{l}\text { Showcase for other } \\
\text { vulneravle areas }\end{array}$ & $\begin{array}{l}\text { Lack of maitenance } \\
\text { will affect the } \\
\text { function of the basins }\end{array}$ \\
\hline $\begin{array}{l}\text { Reduce lack of } \\
\text { space }\end{array}$ & $\begin{array}{l}\text { Less space than a } \\
\text { normal house }\end{array}$ & $\begin{array}{l}\text { The municipality } \\
\text { wants to expropriate } \\
\text { the land from PT KAI }\end{array}$ & $\begin{array}{l}\text { The land is owned by } \\
\text { PT KAI, its hard to } \\
\text { get contract for } \\
\text { building floating } \\
\text { house }\end{array}$ \\
\hline $\begin{array}{l}\text { Nearly affected by } \\
\text { land subsidence }\end{array}$ & $\begin{array}{l}\text { Providing a legal } \\
\text { floating house } \\
\text { rewards illegal } \\
\text { housing }\end{array}$ & & $\begin{array}{l}\text { Collecting a weekly } \\
\text { fee from inhabitants is } \\
\text { not always working } \\
\text { well }\end{array}$ \\
\hline $\begin{array}{l}\text { Instead of } \\
\text { replacing people } \\
\text { can stay in their } \\
\text { neighborhood }\end{array}$ & & $\begin{array}{l}\text { It could be unsave for } \\
\text { young children }\end{array}$ \\
\hline $\begin{array}{l}\text { Providing security } \\
\text { of tenure }\end{array}$ & & & \\
& & & $\begin{array}{l}\text { Providing a house for } \\
\text { inhabitants could } \\
\text { make other people } \\
\text { jealous }\end{array}$ \\
\hline $\begin{array}{l}\text { Good location for } \\
\text { fishermen }\end{array}$ & & $\begin{array}{l}\text { Focus is now on } \\
\text { implementing the } \\
\text { Banger Polder and not } \\
\text { on floating houses }\end{array}$ \\
\hline
\end{tabular}


In order to improve the social acceptance, these factors should be strengthening. Below follows for every factor a recommendation for the improvement of the social acceptance:

a. Relative advantage

At this moment inhabitants do need see enough advantage of a floating house. Improving information about floating houses and about the current situation can help to improve see the advantage of a floating house.

b. Compatibility

The compatibility of floating houses in Semarang is low. This is hard to break through. This can only be changed by experience. Experience will change the norms of inhabitants. When living on floating platforms will be become more regular the compatibility will increase with the developing. According to stakeholder the step into floating houses is already a big change for inhabitants. Therefore recommends to start the floating concept without the self-sufficient system. With a selfsufficient system the compatibility will be lower and it will therefore be harder to achieve the desired compatibility.

c. Complexity

The technology of a floating house is not very complex. The most complex item of the concept is the self-sufficient system.

d. Trialability

The opportunity to try an innovation will help increase the social acceptance which has a positive effect on the diffusion of the technology. A trial or pilot will therefore be recommended. With a pilot project the inhabitants can see how the concept is working. The perception of risk for a floating house is quite high (people still see too much risks). With a floating pilot people are able to experience and see how this concept is working, this will reduce the perception of risk. With improving the knowledge and decreasing the perception of risk, the social acceptance will grow.

\section{Conclusions and Recommendation}

\subsection{Conclusions}

Depend on the research result, it can be concluded that the social acceptance of the inhabitants is quite low, but there is potential because they see positive elements in a floating house. The main criteria why the social acceptance is low is because they don't know the concept. By improving this, the social acceptance will probably also become higher. In order to understand the circumstances it is withal important to interview stakeholders and experts who can explain and clarify the context. Besides they can give their opinion about the project which gives a more nuanced view on the topic.

Table 3. Conclusions of Research

\begin{tabular}{ll}
\hline \multicolumn{1}{c}{ Concern } & \multicolumn{1}{c}{ Reason } \\
\hline Costs & According to the interviewee the costs for a floating house are too much \\
\hline Land owner & $\begin{array}{l}\text { PT KAI is the owner of the land. They are reluctant for building houses } \\
\text { on their land and provide legal houses. }\end{array}$ \\
\hline Juridical & $\begin{array}{l}\text { A regulation of the government is required for floating houses because in } \\
\text { Semarang it is still illegal to build above the water }\end{array}$ \\
\hline Maintenance & $\begin{array}{l}\text { People in Kemijen don't maintain their houses properly. This will affect } \\
\text { the function of the basins according to the interviewee. } \\
\text { The dirty culture is aproblem in Kemijen. This affects the environment } \\
\text { and makes it unhealthy to live above the water. Change of mind-set is } \\
\text { needed to make living on water suitable. }\end{array}$ \\
\hline
\end{tabular}




\begin{tabular}{ll}
\hline Material & The conditions of the water should be measured before implementing a \\
& floating structure. If the water still contains salt, the material of the \\
floating structure should be made suitable for it. \\
House made of bamboo and wood will not be accepted by inhabitants \\
according to the interviewee.
\end{tabular}

\subsection{Recommendations}

Several follow up studies are recommended in order to make this research more valuable and to realize floating house in Semarang in an effective way.

a. For developing floating houses there are several elements that have to be studied first. Social acceptance is only one of these elements. Extensive research into the financial, juridical and technical aspects is still lacking. Research into these elements should be gathered in follow up studies for the case of Semarang. So is it important to know the exact juridical bottlenecks for building on water in Semarang.

b. Financial research would also be important. According to the survey most inhabitants do have insufficient income to pay for a floating house, there are two options for an implementation : reducing the costs of a floating house, or to find financial supporters for the inhabitants. This would be an interesting option to do research about.

c. A follow up study should also consist a research into the juridical aspects. Building on water is still not legal in Indonesia and therefore the law should probably be adjusted. Besides the land owner is still reluctant in building legal houses on its land. Research about the law and discussions with the land owner are therefore required to start a pilot project.

\section{Acknowledgment}

Our gratitude goes to the Directorate of Research and Public Service, Ministry of Research, Technology and Higher Education of Indonesia that has funded this research, Civil Engineering Department of UNISSULA, Water Management Department of Rotterdam University and all those stakeholders who participated and supported.

\section{References}

[1] Adi, Henny Pratiwi; Wahyudi, S. I. (2020). An Analysis of Plastic Barrels as a Platforms Material of Floating House in Coastal Areas An Analysis of Plastic Barrels as a Platforms Material of Floating. In IOP Conference Series: Earth and Environmental Science. https://doi.org/10.1088/1755-1315/498/1/012066

[2] Adi, H. P., \& Wahyudi, S. I. (2015). Analysis of Drainage System Management in The Netherlands , France and Indonesia. In Proceedings of International Conference " Integrated Solutions to Overcome The Climate Change Impact on Coastal Areas " (pp. 1$8)$.

[3] Adi, H. P., \& Wahyudi, S. I. (2018). Tidal Flood Handling through Community Participation in Drainage Management System ( A case study of the first water board in Indonesia ). International Journal of Integrated Engineering, 10(Civil \& Environmental Engineering), 19-23. https://doi.org/https://doi.org/10.30880/ijie.2018.10.02.004

[4] Adi, H. P., Wahyudi, S. I., \& Sudarmono, C. S. (2020). Comparison analysis of expanded polystyrene system ( eps ) and polyvinyl chloride ( pvc ) pipe as platform material of floating buildings in the coastal areas of Semarang. Journal of Physics : Conference Series, 1444(012047). https://doi.org/10.1088/1742-6596/1444/1/012047

[5] Asrasal, A., Wahyudi, S. I., Adi, H. P., \& Heikoop, R. (2018). Analysis of floating house platform stability using polyvinyl chloride ( PVC ) pipe material. MATEC Web of Conferences 195, 02025, 1-8. 
[6] Ham, R. C. B. Van, Schuller, M. L., Heikoop, R., A, H. P., \& Wahyudi, S. I. (2015). The Social Aspects in Water Management of Semarang's Drainage System ( Case Study of Banger Polder and Water Board BPP Sima ). In Proceedings of International Conference "Issue, Management and Engineering in The Sustainable Development on Delta Areas, UNISSULA Semarang (Vol. 1, pp. 1-12).

[7] Purwito. (2002). Mesurement of Losses in House Buildings Due to sea Level Rise on The River Bank. In Prosiding Puslitbangkim.

[8] Santosa, D. E., W, B. A., S, V. F., Prabowo, I., \& Dwinanda, O. (2017). Amphibian House as an Ecological to Overcame Tidal Flood. In Proceeding of National Seminar of Architecture Populis (pp. 27-39).

[9] Wahyudi, S. I., Adi, H. P., \& Lekkerkerk, J. (2019). Handling Solution Tidal Flood in Kaligawe Area by Polder System Drainage. International Journal of Innovative Technology and Exploring Engineering, 9(2), 1104-1109. https://doi.org/10.35940/ijitee.L3450.129219

[10] Watanabe, C.M. Wang, T. U. dan T. M. (2004). Very Large Floating Structures: Applications, Analysis And Design. Singapore: Centre for Offshore Research and Engineering National University of Singapore. 